\title{
The Hungry Bob Fire \& Fire Surrogate Study: A 20-Year Evaluation of the Treatment Effects
}

\author{
George L. McCaskill \\ Forestry \& Range Sciences Laboratory, USDA Forest Service, La Grande, OR 97850, USA; \\ georgemccaskill@fs.fed.us; Tel.: +01-541-962-6533
}

Received: 9 November 2018; Accepted: 26 December 2018; Published: 28 December 2018

\begin{abstract}
The Hungry Bob fuels reduction project was part of a 12-site National Fire and Fire Surrogate (FFS) network of experiments conducted across the United States from the late 1990s through the early 2000s to determine the regional differences in applying alternative fuel-reduction treatments to forests. The Hungry Bob project focused on restoration treatments applied in low elevation, dry second-growth ponderosa pine (Pinus ponderosa subsp. ponderosa (Douglas ex C. Lawson) and Douglas-fir (Pseudotsuga menziesii subsp. glauca (Beissn.) Franco forests of northeastern Oregon. Treatments included a single entry thin from below in 1998, a late season burn in 2000, a thin (1999) followed by burning (2000), and a no-treatment control. This paper represents results 20 years after treatments and focuses on the treatment effects upon tree diameter growth, crown health, and ladder fuel conditions within the dry eastside stands. The Thin + Burn units produced the best diameter growth in ponderosa pine trees, whereas the Thin units had the best growth for Douglas-fir. The Burn treatment did not improve diameter growth over the Controls. The Thin + Burn treatments also produced trees with the highest tree crown ratios. The Burn unit trees had lower crown ratios compared to the Control trees. The crown reduction (reduction in tree crown ratio since 2004) was largest in the Burn-only units and smallest in the Thin + Burn units. Finally, the heights to the lower tree crowns were highest in the Thin + Burn trees and lowest in the Burn unit trees. Based upon the 20-year responses, the Thin + Burn treatments produced the best conditions for stand growth, while limiting fire stress upon residual tree crowns. It also proved most effective at reducing ladder fuels as represented by higher tree crown heights.
\end{abstract}

Keywords: mechanical thinning treatments; prescribed fire; seasonally dry forests; restoration

\section{Introduction}

There are a number of reasons why fire-adapted forest ecosystems in the western United States have departed from their pre-settlement conditions. Aggressive fire suppression efforts, past livestock grazing, farm abandonment, and poor harvest prescriptions are some actions which have contributed to creating denser forests with greater numbers of small-diameter trees and heavier fuel loads [1-3]. These forest conditions in dry eastside environments lead to a general deterioration of the integrity of forest ecosystems and a higher probability of large, high-severity, stand-replacing fires [4].

Such conditions are prevalent in Columbia ponderosa pine (Pinus ponderosa subsp. ponderosa (Douglas ex C. Lawson)) forests with historically short-interval, low-to-moderate severity fire regimes [5-7]. Their associated species, starting with the most shade and competition intolerant, includes quaking aspen (Populus tremuloides Michx.), western larch (Larix occidentalis Nutt.), Douglas-fir (Pseudotsuga menziesii var. glauca (Beissn.) Franco), lodgepole pine (Pinus contorta Dougl. ex Loud), and grand fir (Abies grandis (Dougl. ex D. Don) Lindl.) or sub alpine fir (Abies lasiocarpa ((Hooker) Nuttall.). We found the forest stands within the Hungry Bob site to be dominated by second-growth ponderosa pine with a smaller component of Douglas-fir. Ponderosa pine is a very drought-tolerant 
species growing well in coarse soils and is also shade-intolerant requiring disturbance to open up stands. This species also prefers bare mineral soil for seed germination. Ponderosa pine trees have thick bark and tighter needle bunches around their terminal buds making them somewhat resistant to fire mortality while in the sapling stage. All of these traits make ponderosa pine ecologically adapted to interior dry sites that experience frequent fire disturbance. Douglas-fir trees on the other hand, prefers wetter sites, does not require bare mineral soil for seed germination, and does not develop fire-resistant morphology until adulthood [8]. For ponderosa pine trees to survive and develop, they must be genetically adapted to the local conditions. For example, the environmental interval in which ponderosa pine populations show habitat specificity is approximately $453 \mathrm{~m}$ (1380 feet (ft.)in elevation or intervals of 38 frost-free days. The narrowest habitat specificity for any of the associates of ponderosa pine occurs with Douglas-fir which has an elevation interval of only $113 \mathrm{~m}(650 \mathrm{ft}$.) or intervals of 18 frost-free days [9]. Genetically, ponderosa pine is considered to have an intermediate level of adaptation to differing sites compared to Douglas-fir, which is considered to be a specialist or site specific.

These conditions require land managers to incorporate the restoration ecology concepts of resistance and resiliency into silviculture [10]. Restoration ecology introduces the idea that the forest ecosystem of concern is degraded and needs to be restored to some "self-renewing" condition [11]. This realization is usually followed by an effort to try and identify the historical range of variability (HRV) for the specific ecosystem with an intent to identify the reference conditions [12]. The report from the Sierra Nevada Ecosystem Project highlighted these problems and explained the need for large scale and strategically located thinning (especially of ladder trees), fuels reduction treatments, and the use of prescribed fire [13-16]. The result of this report was the establishment of the National Fire and Fire Surrogate Research Network involving the application of a set of fuel reduction treatments applied across the nation and under a common experimental design [17]. In early January 2000, funding for a five-year national study of "the consequences of Fire and Fire Surrogate treatments" (F\&FS) was awarded to the network steering committee representing 13 sites from the Pacific Northwest to Florida [18].

The Hungry Bob location $(45.6296,-117.2463)$ was selected as one of the sites and the short-term ( $<5$ years post-treatment) results of the treatments were evaluated [19,20]. We re-measured a subset of the national core response variables within the Hungry Bob F\&FS site in order to obtain the mid-term (17-20 years) effects of fire and thinning on the productivity and structure of east-side ponderosa pine in interior Oregon. The specific objectives of the re-measurement were to determine how the different combinations of fire and thinning impacted the diameter growth and crown conditions of the residual ponderosa pine and Douglas-fir trees over a mid-term (20-year) period. Diameter growth and live crown ratio are two good metrics for determining the general health of trees within each of the treatment units. We also wanted to evaluate how much individual tree crown ratios had reduced since 2004 to determine if delayed conifer mortality from prescribed fire was still apparent at a longer timeframe of 20 years [21]. We finally measured the heights to lower crowns to determine if a stand's resistance to crown fires still existed after 20 years. Height to the lower crown of trees is a good metric for evaluating a treatments effectiveness at removing ladder fuels. A fuel load analysis, the life stages of snags and coarse woody debris, along with the results of soil chemical testing, will be evaluated in a future manuscript.

\section{2. .Materials and Methods}

\subsection{Site Description}

The Hungry Bob research site is found within the Blue Mountain Ecoregion of Oregon and consists of a complex of mountain ranges that are lower and more open than the neighboring Cascades or the Northern Rockies. Like the Cascades, but unlike the Northern Rockies, the Blue Mountains are mostly volcanic in origin. However, the core of the Blue Mountains is the Wallowa Mountain range, which is composed of granitic intrusives, deep sea sediments, and metamorphosed rocks [22]. 
Much of Blue Mountains are grazed by cattle, distinct from the Cascades. The Blue Mountain Basins sub-ecoregion includes the Wallowa valley, which contain fault-bounded "grabens" or depressions filled with sediments. The Wallowa valley also has a marine-moderated climate and moisture-retaining loess soils. The valley receives stream flow from snowpack on the surrounding mountains. Most of the floodplain wetlands have been drained for agriculture.

Hungry Bob F\&FS research site is found within the Wallowa Valley Ranger District of the Wallowa-Whitman National Forest in northeast Oregon [23]. The experimental site specifically lays out between the Davis and Crow creek drainages, $45 \mathrm{~km}$ north of Enterprise, Oregon (Figure 1). The forested stands are dominated with more than $75 \%$ second-growth ponderosa pine trees mixed with another 21\% Douglas-fir trees. Western larch, lodgepole pine, and grand fir make up less than 4 percent of the stocking, where they are found prominently growing in the shaded, moist canyons. The area was intensely managed between the early 1900s through the middle of the 1990s, with prescribed fire being actively planned for over the last 30 years [23]. As a result, the stands in 1995 were composed of a dense stocking of trees, the majority having diameters less than $25 \mathrm{~cm}$. The original fieldwork at the Hungry Bob Fire \& Fire Surrogate site was implemented in 1997 in response to the dense structural conditions.

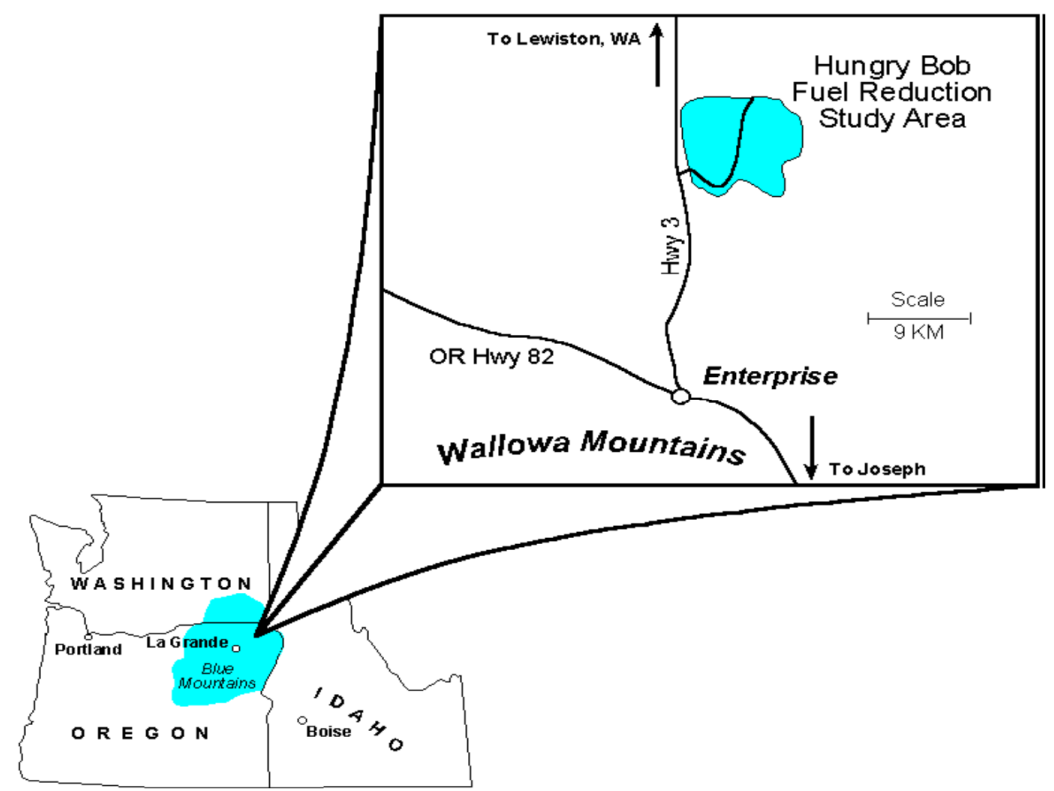

Figure 1. Location of the Hungry Bob Fuel Reduction Project in northeastern Oregon, a site in the national F\&FS network.

\subsection{Field Design}

The following suite of four F\&FS treatments was applied at the Hungry Bob:

1. Untreated control (Control);

2. Prescribed fire only, with periodic reburns (Burn);

3. Initial and periodic cutting, each time followed by physical removal of large residue; no use of prescribed fire (Thin);

4. Initial and periodic cutting, each time followed by prescribed fire (Thin + Burn).

The study was implemented under a complete randomized experimental design of four treatments and four replications, resulting in a total of 16 experimental units. Three Control units were combined into one unit for analysis where the combined unit size was greater than 10 ha, even though one of the three units had a different species composition, stand structure, and aspect. There were also two Thin + Burn units which were combined for the same purpose [24]. The 2017 field season was a partial remeasurement of 218 of the 389 1/25 ha fixed plots located within the 16 experimental units. The 
treatment units average 14.6 ha in size, having pre-treatment averages of 200 trees per ha for stand density and $25 \mathrm{~m}^{2}$ of basal area. All of the Burn, Thin, and Thin + Burn treatment units are located along ridgetops, making prescribed fire easier to control. Two of the six Control units are located in moist canyon bottoms where grand fir, lodgepole pine, and western larch can be found.

Guiding the original implementation of the restoration treatments at the Hungry Bob site were some short-term desired future conditions for the stands after the initial set of treatments [24]. They were reduction of stand basal area, reduction of coarse ground fuel loads, and removal of ladder fuels.

\subsection{Stand Structure}

Total live overstory canopy cover was estimated, taken with a GRS densitometer at five regularly spaced points, points are at the plot center and at each cardinal direction, $2 \mathrm{~m}$ from plot center. All trees were inventoried by species and noted as live or dead, diameters measured to the nearest $0.1 \mathrm{~cm}$ with a diameter tape at $1.37 \mathrm{~m}$ in height, total tree height and height to lower crown were measured to the nearest $0.1 \mathrm{~m}$ with a laser, live crown ratio was estimated ocularly to the nearest $10 \%$, and the tree was characterized as undamaged or damaged with severity indices. The number on the tree tag was recorded for identifying the previous collected field data. Mean annual increment was calculated by subtracting diameters in 2004 from diameters at 2017, divided by number of years. Crown reduction was obtained by subtracting the crown ratio in 2017 from the crown ratio in 2004 .

\subsection{Data Analysis}

Since we wanted to conduct an updated statistical analysis for evaluating each set of treatment units as a separate entity, resulting in a unbalanced number of plots distributed between treatments, while also accounting for both stand disturbances and tree mortality, it became more appropriate to analyze the treatments under a unbalanced block design utilizing a linear mixed-model incorporating the Residual Maximum Likelihood (REML) function to process non-normal data where sample sizes between treatment units are not equal. Residual Maximum Likelihood (REML), also known as restricted maximum likelihood, is now the standard method for estimating variance parameters for particularly unbalanced data. The main attraction of the REML model is that it can handle a much wider class of variance models than simple variance components while producing unbiased estimates for both variates and covariates. It can also detect any interactions between the random experimental blocks and the fixed effects from treatments $[25,26]$. The mixed-model fixed effects were diameter-at-breast-height (dbh), mean annual increment (MAI), tree height, crown ratio, crown ratio reduction, lower crown height, and the total number of trees impacted by each treatment, while the random effects were the four blocks, containing 4 repetitions per block, within the framework of an unbalanced block design (Proc Mixed) while using SAS version 9.4 [27]. Significant treatment effects were determined using differences between Least Squared Means, while hypothesis testing for differences between treatments was accomplished by using Fisher Least Significant Difference (LSD), while differences between treatments and the control was tested by Dunnett's Hsu t-test for multiple means comparison. Both tests utilized an alpha of 0.05 and a two-tailed confidence interval of 95\% [28].

\section{Results}

Those units where mechanical thinning was followed by burning (Thin + Burn), contained the population of ponderosa pine trees with the highest average diameter growth rates (Table 1). The Thin treatments produced the highest growth rates for the Douglas-fir stocking, whose results were highly variable due to significantly smaller sample sizes (Figure 2). Trees within the Burn units failed to produce growth rates significantly different than the trees measured from the Control units (Table 1; Table 2). Douglas-fir trees were also measured to have the highest average tree crown ratios of all the tree species (Figure 3). The Burn units were the only treatments to contain trees with average tree crown ratios lower than the trees measured from the Control units (Figure 3; Table 3). The measured trees from the Burn units also had significantly greater tree crown reductions (decrease in tree crown 
ratios since 2004) than trees measured from the Control or the Thin + Burn units (Table 3). In contrast, trees within the Thin + Burn units had significantly higher crown ratios than the Burn unit trees and experienced significantly less crown ratio reductions than measured trees from within any of the other treatment units, including the Control units (Table 3). This was especially the case when focusing solely on ponderosa pine, which makes up more than $75 \%$ of the stocking (Figure 4 ). When considering ladder fuels, the trees within the Thin+Burn units had significantly higher average heights to their lower crowns than measured on trees from any of the other treatment units, including the Control units (Table 1; Figure 5). Whereas, the trees measured from within the Burn units had significantly lower heights to the bottom of their tree crowns compared to the trees measured from the Control or Thin + Burn units (Table 1; Figure 5).

Table 1. Average increases in stand diameter-at-breast height $(\triangle \mathrm{DBH})$, mean annual increment (MAI), crown ratio reductions by percent, and average heights to lower crowns for all live trees, following a Thin+Burn, Thin, or Burn, 17 years after treatments, as compared to the Controls in second-growth ponderosa pine forests of Northeastern Oregon. Confidence intervals (CI) are at 95\%.

\begin{tabular}{|c|c|c|c|c|c|c|}
\hline Treatment & $\mathbf{N}$ & & $\Delta \mathrm{DBH}(\mathrm{cm})$ & MAI (cm) & $\begin{array}{l}\text { Crown Ratio } \\
\text { Reduction (\%) }\end{array}$ & $\begin{array}{c}\text { Lower Crown } \\
\text { Height (m) }\end{array}$ \\
\hline \multirow{2}{*}{ Thin + Burn } & \multirow{2}{*}{306} & \multirow{2}{*}{$\pm \mathrm{CI}$} & 4.0366 & 0.3105 & 6.3725 & 5.35 \\
\hline & & & 0.2018 & 0.0155 & 1.3522 & 0.29 \\
\hline \multirow{2}{*}{ Thin } & \multirow{2}{*}{461} & \multirow{2}{*}{$\pm \mathrm{CI}$} & 3.5427 & 0.2725 & 9.4902 & 4.57 \\
\hline & & & 0.1955 & 0.0150 & 1.4358 & 0.25 \\
\hline \multirow{2}{*}{ Control } & \multirow{2}{*}{534} & \multirow{2}{*}{$\pm \mathrm{CI}$} & 2.8182 & 0.2168 & 8.0431 & 4.79 \\
\hline & & & 0.1627 & 0.0125 & 1.2414 & 0.25 \\
\hline \multirow{2}{*}{ Burn } & \multirow{2}{*}{409} & \multirow{2}{*}{$\pm \mathrm{CI}$} & 2.6809 & 0.2062 & 13.1907 & 4.17 \\
\hline & & & 0.1764 & 0.0136 & 1.2851 & 0.25 \\
\hline
\end{tabular}

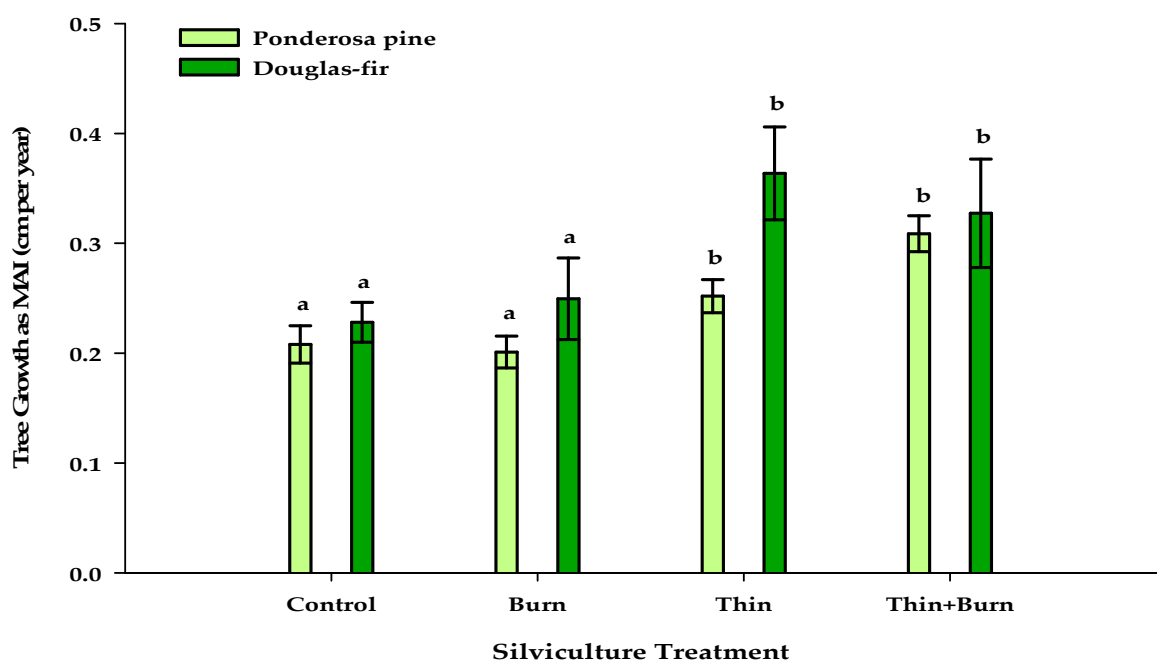

Figure 2. Calculated mean annual increment (MAI) in cm per year for ponderosa pine and Douglas-fir trees by silvicultural treatment. 
Table 2. Differences in least-square means \pm 1 (S.E.) for stand diameter-at-breast height (DBH) measured in 2017 and calculated mean annual increment (MAI) for all live trees; following a Thin + Burn, Thin, or Burn, 17 years after treatments, as compared to the Controls (C) or Burn, in second-growth ponderosa pine forests of Northeastern Oregon. Confidence intervals in parenthesis () are at $95 \%$.

\begin{tabular}{|c|c|c|c|c|c|c|}
\hline Treatment & $\begin{array}{l}\text { Stand DBH } \\
(\mathrm{cm})\end{array}$ & $d f$ & $p$ & $\begin{array}{c}\text { MAI } \\
\text { (cm per year) }\end{array}$ & $d f$ & $p$ \\
\hline Burn vs C & $2.76(1.6)$ & 408 & 0.0010 & $\begin{array}{c}0.0001 \\
(0.0197)\end{array}$ & 408 & ns \\
\hline Thin vs $C$ & $0.94(1.7)$ & 460 & $n s$ & $\begin{array}{c}0.0621 \\
(0.0199\end{array}$ & 460 & $<0.0001$ \\
\hline Thin + Burn vs C & 4.09 (1.9) & 305 & $<0.0001$ & $\begin{array}{c}0.1021 \\
(0.0213)\end{array}$ & 305 & $<0.0001$ \\
\hline Thin+ Burn vs Burn & $1.77(1.6)$ & 305 & 0.0290 & $\begin{array}{c}0.1159 \\
(0.0221)\end{array}$ & 305 & $<0.0001$ \\
\hline
\end{tabular}

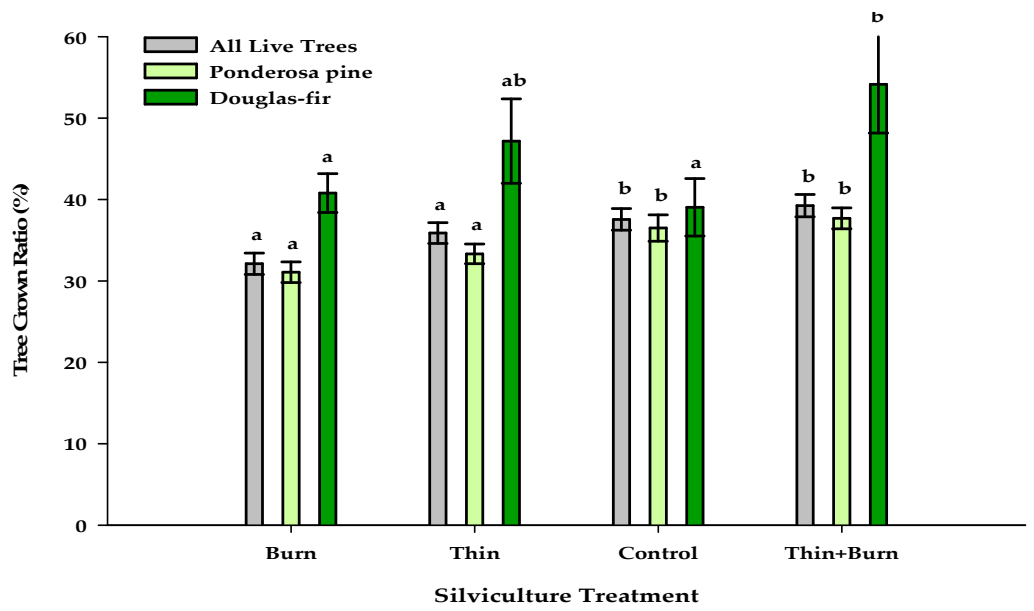

Figure 3. Tree crown ratios in percent of all live, ponderosa pine, and Douglas-fir overstory trees by silvicultural treatment.

Table 3. Differences in least-square means \pm 1 (S.E.) for tree crown ratios by percent measured in 2017 and the calculated reduction in crown ratio for all live trees; following a Thin+Burn, Thin, or Burn, 17 years after treatments as compared to the Controls (C) or Burn, in second-growth ponderosa pine forests of Northeastern Oregon. Confidence intervals in parenthesis () are at $95 \%$.

\begin{tabular}{ccccccc}
\hline Treatment & $\begin{array}{c}\text { Crown } \\
\text { Ratio (\%) }\end{array}$ & $d f$ & $p$ & $\begin{array}{c}\text { Crown Ratio } \\
\text { Reduction }(\boldsymbol{\Delta} \%)\end{array}$ & $\boldsymbol{d f}$ & $\boldsymbol{p}$ \\
\hline Burn vs C & $-5.84(1.8)$ & 408 & $<0.0001$ & $5.23(1.8)$ & 408 & $<0.0001$ \\
Thin vs C & $1.59(1.8)$ & 460 & $n s$ & $1.41(2.0)$ & 460 & $n s$ \\
Thin + Burn vs C & $1.23(2.2)$ & 305 & $n s$ & $-3.81(2.1)$ & 305 & 0.0003 \\
Thin + Burn vs Burn & $7.24(2.0)$ & 408 & $<0.0001$ & $-7.27(1.9)$ & 408 & $<0.0001$ \\
\hline
\end{tabular}




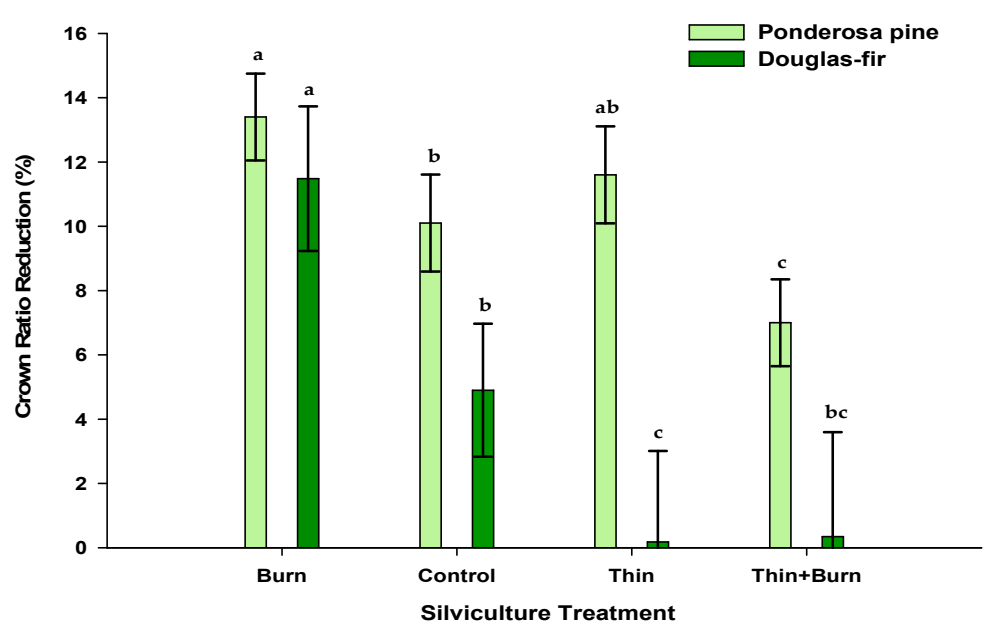

Figure 4. Crown ratio reduction in percent for ponderosa pine and Douglas-fir trees by silvicultural treatment.

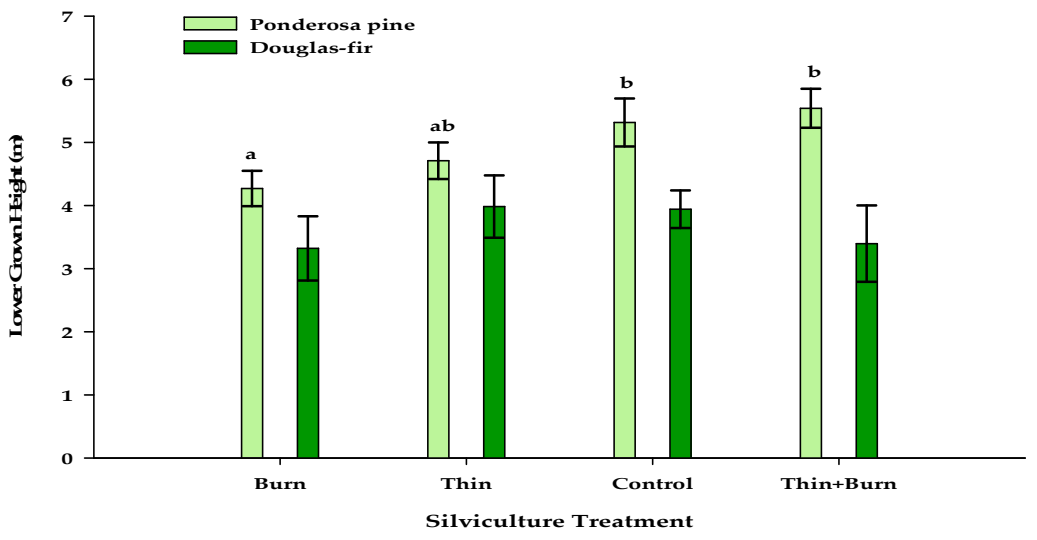

Figure 5. Lower crown heights in meters for ponderosa pine and Douglas-fir overstory trees by silvicultural treatment.

\section{Discussion}

The three treatments (Thin + Burn, Thin, Burn) created distinctly different forest structures, resulting in a divergence in forest growth rates and crown conditions for the intermediate term (17-20 years post-treatment), distinct from the short-term findings of 2001 or 2004 [29-31]. Very little divergence in stand conditions between treatment sites were observed at the short-term evaluation period based upon 2004 field data. Growth was not considered at that time, and neither were changes in tree crown ratios.

Trees measured within the Thin + Burn units, and to a lesser degree the Thin-only units, had improved growth due to greater spacing between residual trees provided by the thinning. Lowering the tree density and removing competing trees and shrubs from the understory also spurs growth [32]. The growth of the residual Douglas-fir trees benefited the most from the thin-only prescription where the smaller Douglas-fir were targeted for removal, leaving only the largest and the healthiest of the Douglas-fir stocking. This is a significant circumstance since the average crown ratios for Douglas-fir trees were dramatically higher than those measured on the ponderosa pine trees, allowing for a greater growth response.

Crown reduction (the decrease in tree crown ratios since 2004) was a very good indicator for measuring delayed fire stress in trees following prescribed burns at the 20-year evaluation period [33]. The trees measured in the Control units had significantly less tree crown reduction than trees measured within the Burn units, illustrating the negative impacts of prescribed fire on the health of tree 
crowns [34]. Thinning before burning produced a health benefit to tree crowns beyond the negative impacts of prescribed fire since trees measured within the Thin + Burn units had significantly less tree crown reductions not only compared to the trees from the Burn units, but also compared to the trees measured from the Control units. Thinning before burning increases the minimum distances between overstory trees reducing the fire stress placed upon individual trees by providing for more heat dissipation during prescribed fire. The greater minimum distances between overstory trees also provides the benefit of additional tree crown growth over tree crowns measured on the Control unit trees. The Control units have over-crowded stands, so tree crown health is impacted negatively from tree competition to a greater degree compared to the Thin + Burn stands where tree density has been dramatically reduced. The measurement of tree crown reduction in 2004 would not have been a significant result as it was for the trees measured in 2017 due to the insufficient time period since treatment.

The removal of ladder fuels by the different fuel treatments can be assessed by measuring the heights between the lower crowns of trees and the ground surface, before and after treatment. Since the Thin + Burn units were found to have the highest average heights between the ground and the lower tree crown, signalizing the effectiveness of this treatment for removing ladder fuels. In contrast, the Burn treatments can be considered least-effective at removing ladder fuels since their measured trees had lower crown heights than measured in trees from the Control units [34].

Two remaining questions for these dry second-growth ponderosa pine forests are: what is the long-term effect of the different treatments on future regeneration [35,36], and what is the optimal minimum spacing between overstory trees, between pole-sized trees, and between sawlog-sized trees for improving restoration prescriptions [37,38]? An assessment of fuel loading, snag life cycles, and soils will be assessed in a future manuscript.

\section{Conclusions}

Only the Thin + Burn and Thin treatments improved tree growth over the trees measured in the Control units. Thin + Burn treatments contained trees with higher crown ratios, but only significantly higher than the trees measured from the Burn units. Burn units had trees with significantly lower crown ratios when compared to trees measured in the Controls. Crown reduction (reduction in the tree crown ratio since 2004) was greatest in trees from the Burn units and lowest in the trees measured within the Thin + Burn units. Height to lower tree crown was highest in trees measured from the Thin + Burn units and lowest in the trees measured within the Burn units.

Based upon the 20-year remeasurement within second-growth ponderosa pine and Douglas-fir stands; the Thin + Burn treatment produced the best conditions for stand growth, while limiting the stress level put upon the residual trees from burning, as reflected by their crown conditions. It was also the best treatment for reducing ladder fuels, indicated by having the highest heights between the ground and the lower tree crowns.

Author Contributions: G.L.M. determined the methodology for the 20-year evaluation, conducted the formal analysis, and wrote the manuscript. G.L.M. also supervised the field sampling crew and the data collection.

Funding: The current research has received no external funding.

Acknowledgments: The author wishes to thank Drs. Andy Youngblood and James McIver for all of their efforts in setting up the Hungry Bob Fuel Reduction study design, its implementation, and overseeing the short-term evaluations. Numerous graduate students, colleagues, and field crews also contributed to this work. The project was initially supported by the Joint Fire Sciences Program of the USDI/USDA.

Conflicts of Interest: The author declares no conflict of interest.

\section{References}

1. Arno, S.F.; Smith, H.Y.; Krebs, M.A. Old Growth Ponderosa Pine and Western Larch stand Structures: Influences of pre-1900 Fires and Fire Exclusion; USDA For. Serv. Intermtn. Res. Sta. Res. Pap, INT-RP-495; United States Department of Agriculture: Washington, WA, USA, 1997; p. 2. 
2. Harrod, R.J.; McRae, B.H.; Hartl, W.E. Historical stand reconstruction in ponderosa pine forests to guide silvicultural prescriptions. For. Ecol. Manag. 1998. [CrossRef]

3. Skinner, C.N.; Chang, C. Fire regimes, past and present. In Sierra Nevada Ecosystem Project: Final Report to Congress; Vol. II Assessments and Scientific Basis for Management Options; Wildland Resources Center Report No. 37; Centers for Water and Wildland Resources, University of California: Davis, CA, USA, 1996; pp. 1041-1069.

4. Keane, R.E.; Agee, J.K.; Fulé, P.; Keeley, J.E.; Key, C.; Kitchen, S.G.; Miller, R.; Schulte, L.A. Ecological effects of large fires on US landscapes: Benefit or catastrophe? Int. J. Wildland Fire 2008, 17, 696-712. [CrossRef]

5. Agee, J.K. Fire and Other Disturbances of Terrestrial Ecosystems in the Eastern Cascades; USDA Forest Service General Technical Report PNW-GTR-344; United States Department of Agriculture: Washington, WA, USA, 1994.

6. Taylor, A.H.; Skinner, C.N. Fire history and landscape dynamics in a late-successional reserve, Klamath Mountains, California, USA. For. Ecol. Manag. 1998, 111, 285-301. [CrossRef]

7. Touchan, R.; Allen, C.D.; Swetnam, T.W. Fire history and climatic patterns in ponderosa pine and mixed-conifer forests of the Jemez Mountains, Northern New Mexico. In Fire Effects in Southwestern Forests: Proceedings of the Second La Mesa Fire Symposium, 1994 March 29-31; Los Alamos, New Mexico; Allen, C.D., Ed.; General Technical Report RM-GTR-286; U.S. Department of Agriculture, Forest Service, Rocky Mountain Forest and Range Experiment Station: Fort Collins, CO, USA, 1996; pp. 33-46.

8. Graham, R.T.; Jain, T.B. Ponderosa pine ecosystems. In Proceedings of the Symposium on Ponderosa Pine: Issues, Trends, and Management, 2004 October 18-21, Klamath Falls, OR.; Ritchie, M.W., Maguire, D.A., Youngblood, A., Eds.; Gen. Tech. Rep PSW-GTR-198; Pacific Southwest Research Station, Forest Service, U.S. Department of Agriculture: Albany, CA, USA, 2005; pp. 1-32.

9. Rehfeldt, G.E. Microevolution of forest trees. In Interior Cedar-hemlock-white Pine Forests, Proceedings of the Symposium on Interior Cedar-Hemlock-White Pine Forests: Ecology and Management, Spokane, WA, USA, 2-4 March 1993; Baumgartner, D.M., Lotan, J.E., Tonn, J.R., Eds.; Department of Natural Resources, Washington State University: Spokane, WA, USA; Pullman, WA, USA, 1994; pp. 92-100.

10. DeRose, R.J.; Long, J.N. Resistance and Resilience: A Conceptual Framework for Silviculture. For. Sci. 2014, 60, 1205-1212. [CrossRef]

11. Society for Ecological Restoration International (SER) Science \& Policy Working Group. The SER International Primer on Ecological Restoration. 2004. Available online: www.ser.org (accessed on 15 September 2018).

12. Addington, R.N.; Aplet, G.H.; Battaglia, M.A.; Briggs, J.S.; Brown, P.M.; Cheng, A.S.; Dickinson, Y.; Feinstein, J.A.; Pelz, K.A.; Regan, C.M.; et al. Principles and Practices for the Restoration of Ponderosa Pine and Dry Mixed-Conifer Forests of the Colorado Front Range; RMRS-GTR-373; U.S. Department of Agriculture, Forest Service, Rocky Mountain Research Station: Fort Collins, CO, USA, 2018; 121p.

13. Millar, C.I. Sierra Nevada Ecosystem Project. Sierra Nevada Ecosystem Project, Final Report to Congress; Vol. I Assessment Summaries and Management Strategies, Centers for water and Wildland Resources, Report No. 36; Cooperative report of the PSW Research Station, PSW Region, USDA, for the Sierra Nevada Framework Project, Sacramento, CA; University of California: Davis, CA, USA, 1996; 209p.

14. Weatherspoon, C.P.; Skinner, C.N. Landscape-level strategies for forest fuel management. In Sierra Nevada Ecosystem Project: Final report to Congress; Vol. II Assessments and Scientific Basis for Management Options; Wildland Resources Center Report No. 37; Centers for Water and Wildland Resources, University of California: Davis, CA, USA, 1996; pp. 1471-1492.

15. Agee, J.K.; Lolley, M.R. Thinning and prescribed fire effects on fuels and potential fire behavior in an eastern Cascades forest, Washington, USA. Fire Ecol. 2006, 2, 3-19. [CrossRef]

16. Mutch, R.W.; Cook, W.A. Restoring fire to ecosystems: Methods vary with land management goals. In The Use of Fire in Forest Restoration; Hardy, C.C., Arno, S.F., Eds.; General Technical Report INT-GTR-341; USDA Forest Service, Intermountain Research Station: Ogden, UT, USA, 1996; pp. 9-11.

17. Edminster, C.B.; Weatherspoon, C.P.; Neary, D.G. The Fire and Fire Surrogates Study: Providing guidelines for fire in future forest watershed management decisions. In Land Stewardship in the 21st Century: The Contributions of Watershed Management; 2000 March 13-16; Tucson, AZ.; Ffolliott, P.F., Baker, M.B., Jr., Edminster, C.B., Dillon, M.C., Mora, K.L., Eds.; Proc. RMRS-P-13; U.S. Department of Agriculture, Forest Service, Rocky Mountain Research Station: Fort Collins, CO, USA, 2000; pp. 312-315. 
18. Youngblood, A.; Metlen, K.L.; Knapp, E.E.; Outcalt, K.W.; Stephens, S.L.; Waldrop, T.A.; Yaussy, D. Implementation of the fire and fire surrogate study-A national research effort to evaluate the consequences of fuel reduction treatments. In Balancing Ecosystem Values: Innovative Experiments for Sustainable Forestry: Proceedings of a Conference; Peterson, C.E., Maguire, D.A., Eds.; Gen. Tech. Rep. PNW-635; U.S. Department of Agriculture, Forest Service, Pacific Northwest Research Station: Portland, OR, USA, 2005; pp. 315-321.

19. Youngblood, A.; Wright, C.S.; Ottmar, R.D.; McIver, J.D. Changes in fuelbed characteristics and resulting fire potentials after fuel reduction treatments in dry forest of the Blue Mountains, northeastern Oregon. For. Ecol. Manag. 2008, 255, 3151-3169. [CrossRef]

20. McIver, J.D.; Youngblood, A.; Niwa, C.; Ottmar, R.; Smith, J.; Tiedemann, A. Hypotheses on the ecological effects of alternative fuel reduction methods. In Proceedings of the Society of American Foresters, Annual Convention, Portland, OR, USA, 11-15 September 1999; Society of American Foresters: Bethesda, MA, USA, 2000; pp. 552-555.

21. Youngblood, A.; Grace, J.; McIver, J.D. Delayed conifer mortality after fuel reduction treatments: Interactive effects of fuel, fire intensity, and bark beetles. Ecol. Appl. 2009, 19, 321-337. [CrossRef] [PubMed]

22. Thorson, T.D.; Bryce, S.A.; Lammers, D.A.; Woods, A.J.; Omernik, J.M.; Kagan, J.; Pater, D.E.; Comstock, J.A. Ecoregions of Oregon (Color Poster with Map, Descriptive Text, Summary Tables, and Photographs); Map Scale 1:1,500,000; U.S. Geological Survey: Reston, VA, USA, 2003. Available online: http:/ / people.oregonstate. edu/ \{\}muirp/FuelsReductionSWOregon/ToolsResources/EcoregionsOregonLevelIVEPA.pdf (accessed on 14 September 2018).

23. McIver, J.; Erickson, K.; Youngblood, A. Principal Short-Term Findings of the National Fire and Fire Surrogate Study; General Technical Report PNW-GTR-860; USDA Forest Service, Pacific Northwest Research Station: Portland, OR, USA, 2012; 210p.

24. Youngblood, A.; Metlen, K.L.; Coe, K. Changes in stand structure and composition after restoration treatments in low elevation dry forests of northeastern Oregon. For. Ecol. Manag. 2006, 234, 143-163. [CrossRef]

25. Chen, W.W.; Deo, R.S. Weighted least squares approximate restricted likelihood estimation for vector autoregressive processes. Biometrika 2010, 97, 231-237. [CrossRef]

26. Studnicki, M.; Madry, W.; Derejko, A.; Noras, K.; Wojcik-Gront, E. Four-way data analysis within the linear mixed model modelling framework. Sci. Agric. 2015, 72, 411-419. [CrossRef]

27. SAS Institute Inc. SAS/STAT®9.4 TM User's Guide; SAS Institute Inc.: Cary, NC, USA, 2014.

28. Ott, R.L.; Longnecker, M. An Introduction to Statistical Methods and Data Analysis, 5th ed.; Cengage learning: Voston, MA, USA, 2001; pp. 1053-1057. ISBN 0-471-38182-9.

29. Stevens, J.T.; Safford, H.D.; Latimer, A.M. Wildfire-contingent effects of fuel treatments can promote ecological resilience in seasonally dry conifer forests. Can. J. For. Res. 2014, 44, 843-854. [CrossRef]

30. Strahan, R.T.; Stoddard, M.T.; Springer, J.D.; Huffman, D.W. Increasing weight of evidence that thinning and burning treatments help restore understory plant communities in ponderosa pine forests. For. Ecol. Manag. 2015, 353, 208-220. [CrossRef]

31. McIver, J.D.; Stephens, S.L.; Agee, J.K.; Barbour, J.; Boerner, R.E.; Edminster, C.B.; Erickson, K.L.; Kerry, A.; Farris, G.; Fettig, C.J.; et al. Ecological effects of alternative fuel-reduction treatments: Highlights of the National Fire and Fire Surrogate study (FFS). Int. J. Wildland Fire 2013, 22, 63-82. [CrossRef]

32. Zhang, J.; Oliver, W.W.; Busse, M.D. Growth and development of ponderosa pine on sites of contrasting productivities: Relative importance of stand density and shrub competition effects. Can. J. For. Res. 2006, 36, 2426-2438. [CrossRef]

33. Thies, W.G.; Westlind, D.J.; Loewen, M.; Brenner, G. A Field Guide to Predict Delayed Mortality of Fire-Damaged Ponderosa Pine: Application and Validation of the Malheur Model; Gen. Tech. Rep. PNW-GTR-769; U.S. Department of Agriculture, Forest Service, Pacific Northwest Research Station: Portland, OR, USA, 2008; $16 \mathrm{p}$.

34. Agee, J.K.; Skinner, C.N. Basic principles of forest fuel reduction treatments. For. Ecol. Manag. 2005, 211, 83-96. [CrossRef]

35. Flathers, K.N.; Kolb, T.E.; Bradford, J.B.; Waring, K.M.; Moser, W.K. Long-Term Thinning Alters Ponderosa Pine Reproduction in Northern Arizona. For. Ecol. Manag. 2016, 374, 154-165. [CrossRef]

36. Long, J.N.; Windmuller-Campione, M.; DeRose, R.J. Building Resistance and Resilience: Regeneration Should Not be Left to Chance. Forests 2018, 9, 270. [CrossRef] 
37. Kerr, G.; Haufe, J. Thinning Practice: A Silvicultural Guide; Version 1.0. United Kingdom Forestry Commission, Publications; Silvan House Publications: Edinburgh, UK, 2011; 54p.

38. USDA Forest Service. Increasing the Pace of Restoration and Job Creation on Our National Forests; United States Department of Agriculture, Forest Service: Washington, DC, USA, 1 February 2012; 9p. Available online: https:/ / www.fs.fed.us/sites/default/files/legacy_files/media/types/publication/field_ pdf/increasing-pace-restoration-job-creation-2012.pdf (accessed on 14 September 2018).

(c)

(C) 2018 by the author. Licensee MDPI, Basel, Switzerland. This article is an open access article distributed under the terms and conditions of the Creative Commons Attribution (CC BY) license (http://creativecommons.org/licenses/by/4.0/). 